\title{
The Impact of Covid 19 Pandemic on the Review of Lawsuits at the Administrative Court of the Republic of North Macedonia
}

\author{
Xhemazie Ibraimi ${ }^{\mathrm{i} *}$ \\ ${ }^{1}$ Faculty of Law, AAB College, Prishtina -Fushë Kosovë, 10000 Prishtina, Kosovo \\ *E -mail of the corresponding author: xhemazie.ibraimi@universitetiaab.com
}

\begin{abstract}
The purpose of this paper is to analyze the impact of Covid 19 Pandemic on the general administrative judicial activity in the Republic of North Macedonia. Considering that Covid 19 as a global pandemic of global proportions is negatively affecting all spheres of life as well as all the most important state functions and activities, we also consider that this situation is affecting the judicial system of the Republic of North Macedonia. Considering that a large number of judges are out of their workplaces and this situation slows down and complicates the procedure for reviewing court disputes, the decision on the violated rights and interests of citizens remains hostage to a global pandemic.
\end{abstract}

In order to analyze the impact of Covid 19 pandemic on the functioning of the judicial system and in particular on the functioning of the Administrative Court in establishing administrative disputes based on lawsuits, we have compared the time periods of the Administrative Court before the pandemic and how many of cases which have been decided on the basis of lawsuits (approved, rejected or dismissed lawsuits) in the last 6 months of 2019, and at the time of the pandemic also how the work of this court has functioned during this pandemic in the total number of lawsuits initiated with the total number of cases on which it has been decided or which have been considered by the judges for the period of time from January to April 2020, the time of pandemic.

The data used in this paper is taken from the reports published on the portal of the Administrative Court of the Republic of North Macedonia.

Key words: Covid-19 pandemic, lawsuits, Administrative Court, Republic of North Macedonia.

DOI: $10.7176 / \mathrm{JLPG} / 101-21$

Publication date:September 30th 2020

\section{Introduction}

In order for the court to start performing its duty, it is necessary for there to be an indictment on the part of the plaintiff as in the administrative dispute the principle applies without an indictment there is no administrative dispute.

The administrative dispute is initiated with an indictment (Article 24, paragraph 1 of the Law on Administrative Dispute of Macedonia). From this provision it can be concluded that the court is not authorized to initiate an administrative dispute on a formal initiative (ex officio (Gelevski \& Davitkovski \& Grizo \& Ana, Administrativno Pravo, Skopje, 2008, p. 522) but an administrative dispute can be initiated only by the indictment. 
This means that when initiating an administrative dispute, the principle of the party or the principle of private maxim applies, but not the principle of official maxim.

\section{Procedure based on the lawsuit}

\subsection{Lawsuit, notion and form}

The lawsuit has formal legal significance and material legal significance (Sokoli, E Drejta Procedurale Administrative, Prishtinë, 2014, fq. 231).

The legal-material significance of the lawsuit is identified with the claim of the lawsuit with which the plaintiff asks the court to annul the challenged administrative act in order to protect his subjective right violated (see: Velimit Ivançeviq, Zakon o upravnom sporu, sa komentarom, Zagreb, 1958, fq. 131). This is an action of the lawsuit in conflict for the legality of the administrative act, because with the annulment of the disputed administrative act, the reasons are eliminated for which the plaintiff could not realize his right and interest based on law.

In the conflict of full jurisdiction, the purpose of the lawsuit is not only the annulment of the disputed administrative act but the purpose is, the creation, change or abolition of a certain legal relationship, respectively legal situation (Ibraimi, , Administrative Conflict - Instrument for Control of Legality of Administrative Acts, Tetovo, 2018, pg.146).

The lawsuit in the formal-legal sense is a submission by which the administrative dispute is initiated. Its submission represents the first action of the procedure by which the claim of the lawsuit must be resolved.

The difference between the legal-material side and the legal-formal side of the lawsuit is also expressed in certain provisions of the Law on Administrative Dispute, which have to do with the reasons for dismissing the lawsuit. Thus, the legal-formal reasons for dismissal of the lawsuit are listed in (Article 25, paragraph 1 of the Law on Administrative Dispute), while the legal-material reasons for dismissal of the lawsuit are listed in (Article 26, Law on Administrative Disputes).

When it comes to the form of the lawsuit, this condition should be understood that the law does not require any special form of the composition of the lawsuit. However, the law enumerates the minimum conditions that the indictment must contain in order for the court to accept it. Thus (Article 23, Law on Administrative Conflict) it is stated that an indictment must contain: the name, surname and place of residence of the plaintiff, respectively the name and headquarters of the legal entity registered in the central register, the act against which the indictment is directed, the reasons for which the plaintiff sues the body, as well as the direction and breadth of the claim by submitting the proposal, the administrative act to be annulled.

The indictment must be accompanied by the act against which the indictment was initiated, also in its original or copied form (Ibraimi, Administrative Conflict-Instrument for Control of Legality of Administrative Acts, Tetovo, 2018, p.146).

The indictment is usually submitted in two copies, in order for the respondent body or organization to respond to the indictment. 
If interested persons are also involved in the conflict, the indictment must be submitted in the same number of copies as the interested parties are.

The indictment must also state the reasons for which the plaintiff deems that the act is illegal, respectively the reasons for which the plaintiff deems that his right and interest based on law has been violated. I.e. it is not sufficient for the indictment to state in general the reasons that the contested act is illegal. Finally, the plaintiff must state in what direction and to what extent he proposes the annulment of the disputed administrative act.

Only one administrative act can be annulled with the lawsuit, in whole or in part, for which the plaintiff must declare in this regard.

Attaching the facts of the lawsuit and its development are free. In the lawsuit, the plaintiff is not obliged to cite the legal provisions which are violated by the act. Although the law does not require a special form of filing a lawsuit, the reasons in the lawsuit must not be vague and contradictory.

The challenged administrative act in original or copied must be submitted together with the lawsuit.

The lawsuit can be completed or amended before the deadline for initiating the lawsuit expires. If the deadline for initiating the lawsuit has expired, the lawsuit can be completed and amended until the court has issued a decision provided that the filing and amendment of the claim does not change the basis of the claimant's claim.

\section{Deadline for initiating a lawsuit}

In order to achieve legal certainty, the Law on Administrative Conflict sets a deadline for initiating administrative dispute. (Law on Administrative Conflict Article 20), provides that the administrative dispute can be initiated within 30 days from the date of submission of the final act to the party. This deadline also applies to the body authorized to initiate a lawsuit, if the administrative act has been submitted to it, in addition to individual acts issued in the election procedure.

If the act has not been served, the body may file the indictment within 60 days from the day of delivery of the administrative act to the party, but if the act has not been served, the indictment is initiated within 30 days from the day of promulgation of the act, respectively of the decision of the Constitutional Court in the Official Gazette of the Republic of Macedonia.

For the indictment against individual acts issued in the election procedure, a deadline of 3 days has been set from the day the act is issued or announced.

For non-fulfillment of administrative contracts, the deadline for initiating a lawsuit is 30 days, from the day when it is confirmed that the obligation has not been fulfilled (Daneva, Upravni Dogovori-Doktorska Disertacija, Skopje, 2004).

The question arises as to what is the nature of the deadline set out in the Law on Administrative Conflict.

It must be emphasized that this deadline is a preclusive deadline, respectively the plaintiff must initiate an administrative conflict with the lawsuit within the legally prescribed deadline and that this deadline can not be extended even by a court decision. 
If the plaintiff does not file an indictment within this deadline, then the plaintiff loses the right to initiate an administrative dispute.

This term obliges both bodies, individuals, legal entities as well as the court.

The deadline starts to run from the day when the act was delivered to the party, unless otherwise provided by a special legal provision (Sokoli, Administrative Procedural Law, Prishtina, 2014, p. 106). Based on this, as a rule, it is not enough for the decision to be notified only to the plaintiff, but it must be served on the party. Thus, if the party has only been notified of the content of the act, the deadline for initiating the lawsuit begins to run from the day of delivery of the act to the party and not from the day of notification of the act to the party. This means that in order for the indictment to be initiated within the legally prescribed deadline, the date of delivery of the challenged act to the party is important and not the date when the party has understood the content of the contested act. It should be noted that in the period of 30 respectively 60, respectively 3 days, the day of delivery of the ruling is not part, respectively the day begins to flow one day later from the day of receipt of the ruling by the party. If the deadline for initiating the lawsuit falls on the day when the court is not working (Sunday or public holiday), the same is extended and expires the following day.

The indictment is submitted directly to the court or by mail.

The day of filing the lawsuit by mail is counted as the day of filing the lawsuit in court. In accordance with the purpose of the law if the indictment was sent by simple postal order, the day when the indictment was received in court is counted as the day of receipt of the indictment. This means for the evaluation of the regularity of the filing of the indictment, it is important when the administrative act was submitted to the plaintiff and when the indictment was received in the court which is competent to review the case.

If the lawsuit is not regular, respectively if it was initiated after the deadlines provided by legal provisions (Article 20, Law on Administrative Dispute) or if the lawsuit was initiated prematurely before the legal deadline in (Article 22, Law on Administrative Conflict), in case of silence of the administration, the court in accordance with (Article 26, paragraph 1, point 1, Law on Administrative Conflict) is obliged to dismiss the indictment with a ruling in the first case as an irregular indictment, while in the case of second as a premature indictment. Upon dismissal of the lawsuit, the court is not issued a meritorious decision on the claim.

If the indictment was not submitted to the court but to another body, while in the Administrative Court the indictment arrives after the expiration of the deadline for initiation, then it will be considered that the indictment was submitted on time if it is found that the plaintiff submitted the indictment to another body and not the court was caused by the plaintiff's ignorance or error. I.e. if due to the submission of the lawsuit by mail to the incompetent Court or incompetent body, the deadline provided by the Law on Administrative Dispute expires, then it will be considered that the lawsuit is not valid, only if the submission of the lawsuit to the Court or incompetent body was caused by the plaintiff's ignorance.

The submission of the lawsuit for initiating the administrative dispute within the legally prescribed deadline is certified by a delivery note, and the same is obliged to be certified by the court where the administrative dispute is conducted.

In any case, the court must certify the regularity of the lawsuit ex officio, and if the delivery note of the challenged act is not sufficient evidence then the court must prove in another way on which day the contested administrative act was served on the plaintiff. 
In the administrative-judicial practice, the question arose as to how the day of filing the indictment in an administrative dispute should be calculated as the day when the plaintiff first filed the indictment. It was decided that in this case the day when the indictment was submitted to the court should be counted as the day when the plaintiff filed the indictment in court for the first time (Grizo \& Gelevski \& Borce \& Ana, Administrativno Pravo, Skopje, 2008, p. 522).

If it is a question of completing the lawsuit which the plaintiff has submitted on his personal initiative and not at the request of the court, in this case the same deadline applies as for filing a lawsuit. Since the Law on Administrative Dispute is not related to the causes of the lawsuit, it does not present an obstacle for the court to take into account the reasons stated in the completion of the lawsuit filed even after the expiration of the deadline for filing the lawsuit.

It can be concluded that the same deadline applies to the submissions and the completion of the indictment as to the filing of the indictment respectively the complaint. When the indictment, respectively the appeal is filed within the legally prescribed deadline, then the submissions and additions are counted as part of the indictment initiated within the legally prescribed deadline even though they were filed after the filing of the indictment.

If the party has not filed a lawsuit within the legal deadline against the final administrative act issued in administrative procedure due to the fact that for the same act has been requested correction of the technical error which was approved, the deadline for initiating the lawsuit will be calculated from the day when the corrected act has been delivered to the party and not from the day of delivery of the conclusion for the correction made.

The case law has taken the position that the deadline for filing a lawsuit stops in the event of the plaintiff's death. This deadline starts from the beginning from the day when the competent court will deliver the ruling for filing the lawsuit to the guardian.

If more than one party with the same interests in the administrative procedure does not appoint a joint authorizer, such quality will have the party who is the first in the joint submission in the administrative procedure or the party who was the first to sign or the first to listed in the submission.

If with the indictment the plaintiff requests the return of the received items or compensation of the damage caused, then in the indictment the claim must be stated both in terms of the items and in terms of the damage caused.

\section{Legal action of the lawsuit in administrative dispute}

In principle, a distinction should be made between the legal action of the complaint as an important legal tool for the realization and protection of the constitutional rights of individuals and other subjects of law in the legaladministrative procedure (Sokol, Administrative Law 2, Third revised edition. , Tirana, 2005, p. 182) and the indictment in the court-administrative procedure ( (Grizo\&Gelevski\&Borçe\&Ana, Administrativno Pravo, Skopje, 2008, fq. 522).

The appeal in the legal-administrative procedure has a suspensive action (Article 231, paragraph 1, Law on Administrative Conflict), which means that the appeal annuls (suspends) the execution of the administrative act against which the appeal is filed. Except for the appeal, there is no suspensive action if it is determined by law or if it is a matter of taking urgent measures, when there is no place for appeal against the administrative act of the body of first instance, or when the cancellation of the execution of the administrative act will cause irreparable damage to the party. 
The lawsuit in the administrative-judicial procedure, as a rule, has no suspensive action (Article 14, paragraph 1, from the Law on Administrative Conflict) and the initiation of the lawsuit does not stop the execution of the challenged administrative act against which the administrative conflict was initiated by of the lawsuit.

Taking into account the non-suspensive action of the lawsuit in administrative dispute, the legislator has provided an exception to this rule. Thus (Article 14, paragraph 2, Law on Administrative Conflict) provides that the lawsuit has suspensive action when the plaintiff so requests when the execution of the contested administrative act would cause irreparable damage to the plaintiff who could hardly to compensate, (When the plaintiff with the execution of the contested administrative act would be caused damage which could hardly be compensated, this especially when the plaintiff with the contested administrative act is obliged to give something, do or not do.

But all these cases can not be treated equally as even among them there are cases when returning to the previous state does not cause any difficulty).

while the annulment of the contested act is not contrary to the public interest, nor would the annulment of the contested administrative act cause irreparable harm to the other party. The conditions for carrying out the suspensive action of the lawsuit are cumulative.

From such a request it can be concluded that in cases when there is no doubt that the execution of the challenged administrative act would cause uncompensated damage to the plaintiff, the execution of the challenged administrative act will not be annulled.if such execution is contrary to the legal interest, as the plaintiff's private interest cannot take precedence over the public interest.If the request for cancellation in this case is rejected, the reasoning must state what the public interest is. If the request for cancellation is rejected on the grounds that the cancellation will cause harm to the other party, it must be stated what is the irreparable damage that would be caused to the other party.

After the request, the competent body is obliged to issue a decision no later than 3 days from the day of receipt of the request. The annulment of the execution of the administrative act will not be allowed even when the annulment of the execution of the disputed administrative act would cause the greatest unpaid damage to the opposite party, even when the first two conditions in this case are met. .

The third condition concerns only the cases when in the conflict besides the plaintiff and the defendant, the third party or interested persons also participate.In this case, in order to refuse the annulment of the execution, it is necessary to take into account that the annulment of the execution will cause qualified damage to the opposite party, respectively damage to a greater extent which could not be compensated.It can be concluded that during the annulment of the execution of the contested administrative act, the legislator is decisive in terms of the second and third condition, respectively the annulment is not contrary to the public interest and the annulment of the execution of the contested administrative act does not cause harm larger the opposite party which could hardly be compensated.In view of the first condition, the legislator does not act in a decisive manner, which can be ascertained by the authorization of the state body, to be able to cancel the execution of the challenged act until the final court decision.

The legislator has allowed the lawsuit to have suspensive action for other reasons, which he has not stated in the Law on Administrative Dispute, provided that it is allowed by the public interest (Article 14 paragraph. 4, Law on Administrative Dispute).

After each request for cancellation, the competent body is obliged to issue a decision no later than 3 days from the day of receipt of the request (Article 14 paragraph.3, Law on Administrative Dispute). 
In accordance with such authorization provided in the Law on Administrative Conflict, the competent body for annulment of the execution of the administrative act is determined (Law on General Administrative Procedure, Article 277), which provides that the execution of administrative acts is done by the body that has decided on the issue in the first instance, unless a special provision stipulates that it be made by another body.

If these bodies are not authorized to own them execute their decisions, the execution of decisions in this case allows and enforces the state administration, in whose jurisdiction the things part of the general administration, if the law is not determine the competence of the other body.

The annulment of the execution of the challenged administrative act is done at the request of the plaintiff or at the initiative of the state body.

The state body may cancel the execution of the challenged administrative act at the request of the plaintiff or on personal initiative. In order for a person to file a request for annulment of the execution of an administrative act, he must first have the capacity of plaintiff in an administrative dispute.

A request for cancellation can be submitted even before the filing of an indictment for administrative dispute, but in this case the plaintiff in the request for cancellation must also present his intention to initiate an administrative dispute. If the challenged administrative act has been executed, then the plaintiff will not need to file a request for annulment of the execution of the administrative act. But in this case he must wait for the decision issued in the administrative dispute, and if the challenged administrative act is annulled, then he has the right to request return to the previous state.

Although the legislator has not foreseen such a situation, obviously the competent body on personal initiative will cancel the execution of the challenged administrative act until the final court decision, it is understood if such cancellation is not against the public interest.

There is a doubt whether the annulment of the challenged administrative act will have a suspensive action. The legislator has not regulated this issue. No proposal can be made for such a request to have such an effect, especially due to the short time limit of 3 days, for a decision based on the request.

The law is not declared even in terms of the possibility to file an appeal against the ruling to the highest body, if the request for cancellation of execution is rejected. Perhaps it would be more reasonable in this case in the Administrative Procedure to use the regular legal remedy Appeal, if the decision was not made by the highest body of administration against whose decision the appeal can not be initiated

In this view there is a suspicion of allowing the indictment against the act of the state body of the second instance for refusing to annul the execution of the administrative act. Although the legislator does not foresee this situation, but according to the general clause according to which an administrative dispute can be initiated against all administrative acts against which a certain legal provision is not excluded the initiation of an administrative dispute is not excluded that an indictment can be filed against these acts.

In this case it would be more than necessary and reasonable for the court to decide at the same time on both the main issue and the indictment against the ruling rejecting the request for annulment of the execution of the challenged administrative act. But in this case the court decisions do not need to be the same. The court will reject the indictment against the decision to refuse the annulment of the execution of the challenged administrative act with a judgment, while in the conflict for the main issue it will annul the contested administrative act. Conversely, the court may annul the ruling rejecting the annulment for execution while rejecting the indictment on the main 
issue.Ligjvënësi ka paraparë që ekzekutimi i aktit të kontestuar administrativ të mund të anulohet deri në përfundimin e vendimit gjyqësorë.

Based on this, at the request of the plaintiff for annulment of the execution of the challenged act, two rulings are possible: either the request for annulment of the execution is rejected or the annulment is approved until the end of the administrative dispute. Although the legislature has not set urgent deadlines when it comes to conflicts that require the annulment of the execution of the contested administrative act, it would be more than necessary for the court to consider such cases immediately.

If the body rejects the plaintiff's request for annulment of the execution of the ruling and the plaintiff is harmed then the plaintiff in accordance with (Article 11, Law on Administrative Conflict), in the same administrative dispute may seek compensation for damage caused. as well as return of items received.

If the competent body that issued the administrative act acts on the basis of the execution of the act until the issuance of the court decision, then the plaintiff may request the court to bring an interim measure for annulment of the execution of the administrative act.

The plaintiff may also request the imposition of an interim measure for the temporary settlement of the case in relation to the disputed administrative relationship if such adjustment to legal relations that last is shown to be unnecessary in order to avoid the most serious consequences or the threatening force. . The court that decides on the basis of the indictment is competent to conduct an interim measure. The court for imposing a temporary measure must decide within 7 days from the receipt of the request, with a decision which must be reasoned. The court may bring the interim measure provided that a guarantee is provided for the eventual damage that may occur to the other party, due to its conduct. Against the decision of the court, the parties have the right to initiate an appeal to the competent court for a decision within 3 days, which based on the appeal is obliged to make a decision within 3 days from the date of submission of the appeal.

In any case, it should be noted that the issue of execution is not raised in every decision, but only in those decisions in which there is something to be executed, i.e. if by administrative act the party has been ordered to do something to give something or not to do. If the party with an administrative act has been denied the request to be granted a right, here too there is nothing to be executed therefore and no execution is expressed.

\section{Stages of administrative court proceedings}

Within the procedure based on the indictment, two basic stages of the procedure can be distinguished (Grizo \& Gelevski \& Borçe \& Ana, Administrativno Pravo, Skopje, 2008, p. 526):

- previous (preliminary) court procedure and

- regular court procedure

Each of these two types of procedure has its own specifics, although in the regular procedure certain issues from the preliminary procedure can be decided, if they are not decided at this stage. 


\subsection{Preliminary administrative-judicial procedure}

Characteristic of the preliminary procedure is that at this stage of the procedure the indictment is not decided in a meritorious manner, respectively the disputed legal issue is not examined,

but the indictment was dismissed on formal grounds, respectively annul the contested administrative act if it contains significant flaws that hamper the assessment of the legality of the act in the material sense.

\subsection{Dismissal of the lawsuit for formal reasons}

(Law on Administrative Conflict, Article 25), stipulates that the chairman of the council, if he finds that the indictment is misunderstood and incomplete, has the right to summon the plaintiff to eliminate the deficiencies of the indictment within a certain period of time., instructing him on what and how to do it, and showing him the need for legal representative and the consequences if he does not act upon the request of the court

If the plaintiff within the deadline set by the president of the court does not eliminate the shortcomings of the lawsuit as they are of the nature that hinder the further work of the court, the court will dismiss the lawsuit as irregular, only if the court does not find that the challenged administrative act has not been annulled.

The court with a ruling at this stage of the procedure will dismiss the indictment if it finds that:

- the indictment is premature $(30,30$, respectively 3 ) or after the expiration of the legal deadline (respectively if the plaintiff does not initiate an indictment within 30,30 , respectively 7 days) or if the plaintiff files an indictment against the so-called " administrative silence "and did not wait for the deadlines set out in (Article 22 Law on Administrative Conflict) to expire.

- The act which is challenged with the indictment is not an administrative act (the subject of the administrative dispute can only be an administrative act, and if the act of the state body against which the indictment is filed does not have the characteristics of an administrative act, the court is obliged to dismiss the indictment).Gjykata me vendim do ta hudhë aktpadinë nëse konstaton se akti i cili kontestohet me aktpadi nuk është akt administrativ në kuptim të Ligjit për Konflikt Administrativ.

We will present some examples where the Administrative Court rejects the charges as unacceptable.

1.The Supreme Court will dismiss the indictment as inadmissible if it finds that the decisions of the scientific-teaching council of the faculty which confirms the approval of the report of the commission for evaluation of the master thesis, do not represent an administrative act in accordance with the Law on Administrative Conflict but opinion scientific and evaluation for the done master's thesis, and for this reason these are not constitutive and resolving acts by which certain rights of the plaintiff are created or annulled, nor are they brought authoritatively by the body holding power in the exercise of public powers. The challenged administrative act which is affected by the indictment does not affect the right of the plaintiff or his direct interest based on law (in this case the court will dismiss the indictment as a result of not having active procedural identification card, as the indictment was filed by a person who is not authorized to initiate an administrative dispute. and it is provided that the administrative act does not affect the right or interest of the plaintiff, it means that it is not decided on his right or direct interest based on law. The law emphasizes the need to prove the fact that the plaintiff does not have an identity card to file a lawsuit. When it comes to the lack of active procedural identification, the indictment is submitted in response and the case file is provided. This reason for dismissal of the lawsuit can be used only in cases when it is not about a right or interest based on law which in this case appears as a plaintiff in the administrative dispute and not in cases where the court 
will establish that with the challenged decision the right of the plaintiff or his direct interest based on law has not been violated.

2. The court with a ruling will dismiss the lawsuit if it finds that the administrative act does not affect the right of the plaintiff.

The Ministry of Internal Affairs of the Republic of Macedonia has filed an indictment with the Supreme Court against the decision of the Government, the commission for review of administrative affairs in the second instance in the field of defense, internal affairs, advocacy and administration with which the appeal was approved. of the person $\mathrm{NN}$, the decision of the plaintiff for registration of residence will be annulled while the case is returned to the repetition of the procedure. The plaintiff in the indictment states that the decision of the first instance was brought in accordance with the law, while the body of the second instance has issued a wrong conclusion regarding the factual situation and has erroneously applied the material provision, proposing that the court annul the decision. challenged and issue a new judgment by which he will confirm the ruling of the first instance. The court, reviewing the indictment and the case file, concluded that the plaintiff does not have an active identification card to initiate an administrative dispute in this case. From the reasoning in accordance with the Law on Administrative Conflict, an administrative dispute can be initiated by a state body even though it does not have the quality of a legal entity, if in the administrative procedure it is decided about its rights and interests. With the indictment, the plaintiff challenges the indictment issued in the procedure in which he was a body of first instance and decided based on the request of the person N.N for registration of residence. Based on it, the court in this case has assessed that it is about the authorization that the Ministry of Internal Affairs has to present the place of residence and stay of citizens and that it is not about the direct rights and obligations of the plaintiff who eventually were violated in the administrative procedure. Since the rights and obligations in this case do not belong to his authorizations as an administrative body which he exercises against the citizens who exercise his right to this body, the Court has found that in this case in the procedure has not been decided for him. the rights and obligations of the plaintiff respectively the Ministry of Internal Affairs. Against the administrative act which is challenged with the indictment an appeal could be initiated while this was not done or was not initiated in time (the court will dismiss the indictment if it finds that the plaintiff did not use it the right to initiate an appeal against the act of the administrative body of the first instance, deriving from the principle of reciprocity in the administrative procedure.Nëse bëhet fjalë për çështje administrative për të cilën nuk mund të udhëhiqet konflikt administrativ (neni 9) nga Ligji për Konflikt Administrativ, Konflikt Administrativ nuk mund të udhëhiqet kundër: akteve të cilët janë të sjellura në punë për të cilët mbrojtja gjyqësore është e siguruar jashtë konfliktit administrativ dhe për lëndë për të cilët në bazë të autorizimeve kushtetuese në mënyrë të drejtëpërdrejtë vendosë Kuvendi dhe Presidenti i vendit përveç vendimeve për emërim dhe shkarkim.

The court will dismiss the lawsuit for compensation of material damage as illegal, due to the illness that the plaintiff acquired during the war as a fighter, as he did not attach or offer an administrative act issued in an administrative procedure in which it was decided to his right or interest, against which an administrative dispute can be initiated. From the reasoning, administrative dispute can be directed against the legality of the administrative act in the concrete case such act has not been served and the plaintiff has not been harmed by the issuance of the administrative act. If there is a final decision issued in conflict on the same issue. In order for the court to dismiss the lawsuit due to the existence of a final court decision, it is necessary for the identity of the right and legal interest and the identity of the party to exist.

In the above mentioned cases, the court will dismiss the indictment in the pre-trial procedure, even before sending the indictment in response to the respondent body. However, if the court in the pre-trial procedure cannot, only on the basis of the indictment and the challenged act attached to the indictment, establish the reasons for dismissal of the indictment, the court is obliged to dismiss the indictment ex officio from the aforementioned reasons. in regular court proceedings.

At the end of this paper we will present the data of the total number of indictments which have been dismissed in the preliminary court proceedings as irregular indictments for the period before the global pandemic, ie: the last 6 months of 2019 are included, as well as the total number of indictments received in the Administrative Court at 
the time of the pandemic as well: the period of operation of the court in the pandemic crisis from January to April 2020 is included, how many indictments have been received and how many indictments have been processed.

\subsection{Regular court proceedings}

If the court does not find irregularities in the indictment, while the indictment is regular then it will send the indictment together with the case file in response to the respondent body and interested persons if any, within a period which can not be shorter. than 8-days and longer than 30-days, from the day of filing the indictment.

In response to the indictment, the respondent body must declare itself on the basis of the allegations in the indictment and is obliged to submit all the case file to the court within the prescribed time limit, if any. If the respondent body does not submit the case file to the court within the prescribed time limit or declares that it cannot deliver it, then the court will decide on the case without the case file (Article 5, Law on Administrative Dispute of RMV ). In the cases of (Article 5), when the court is not able to decide on the case in the absence of case files, then the court with a ruling will impose a fine of up to $20 \%$ of the monthly salary, the body that issued the act challenged respectively the person who has taken the challenged action.

In the indictment and in the response to the indictment, the parties provide facts on which to base their statements, propose evidence to establish the facts and state themselves on the basis of the allegations and evidence presented by the other parties.

The court decides on the limits of the claim of the indictment, but it is not limited only to the reasons stated in the indictment.

The court in dispute based on the indictment decides in public session based on the free assessment of facts and evidence.

The court will take into account all the facts established in the administrative procedure for the issuance of the challenged administrative act and has the right to establish facts and evidence that it deems necessary for the settlement of the dispute. At the request of the court, every public body is obliged to submit to the court all the documents and data at its disposal and which are in the interest of deciding the concrete case, within the deadline determined by the court (Article 36, paragraph). 1, Law on Administrative Conflict). If the body does not act in accordance with (paragraph 1) of this article, the court with a ruling will impose a fine of $20 \%$ of the monthly salary on the person authorized by the public body who for unreasonable reasons has not submitted the documents. respectively the data at its disposal. An appeal against this ruling is allowed to the High Administrative Court, within 15 days from the day of delivery of the ruling to the respondent body.

The court decides in an administrative dispute without holding a hearing in the following cases:

1) If the ruling of the respondent body has been issued in accordance with the legal opinion of the court;

2) If the plaintiff disputes the application of the material provision, and not the determination of the factual situation;

3) When the court decides with a ruling, only in cases of interim measures; 
4) If it finds that the challenged administrative act contains such deficiencies which hinder the assessment of the legality of the act, for which reason it will annul such act.

The chairman of the council or the judge will open the hearing and verify whether all the guests are present, and if the same are not present, whether they have been regularly invited and whether they have justified their absence. If none of the invited parties or representatives of the parties are present to justify their absence then the hearing will begin without their participation, which is chaired by the president of the council or the court. If the court finds that the issue of the dispute has been considered sufficiently to be able to reach a decision, the hearing will be closed and the council will withdraw for deliberation and voting. Minutes are kept for the session. 1.

If the plaintiff during the court procedure, brings another act by which the administrative act which is challenged is amended or annulled, he is obliged to inform the court next to which he is bringing about the adoption of the new act or the change of the act which is challenged by the lawsuit. initiated the administrative dispute as well as the plaintiff, while the court in this case will invite the plaintiff to declare within 15 days, whether he is satisfied with the conduct of the new act or stands behind the indictment, and if so, to state whether it extends the indictment also against the new act issued additionally by the respondent body.

If the plaintiff declares that he is satisfied with the issuance of the new act, then the court will terminate the procedure with a ruling or if within the prescribed time limit he declares that he is not satisfied with the issuance of the new act then the court will continue the procedure.

The court decides on the main issue with a judgment, which is rendered on the basis of personal conviction and assessment of legal and factual facts.

The court will reject the claim of the lawsuit as unfounded if it finds that the procedure pertaining to the contested act has been implemented in accordance with the legal provisions, that the decision is fair and based on law.

The court will also reject the indictment as unfounded even if it finds that there are irregularities in the procedure regarding the issuance of the challenged act which have not influenced the resolution of the dispute, and in case the court finds that the contested act was based on law

If the court finds that the challenged act is illegal, it will approve the claim with a judgment, annul the challenged individual act and decide the administrative issue itself (judgment in full jurisdiction) on the basis of which the new judgment in completely replaces the annulled administrative act.

If the court finds that the public body has not brought the new administrative act within the set deadline, which according to the provisions should have been issued, it will approve the request of the lawsuit with a judgment and will decide the case itself.

The court will annul the disputed administrative act and return it to the body that issued it in the following cases:

- If the respondent body has decided on the basis of free assessment.

- If the nature of the administrative case does not allow for placement in full jurisdiction, respectively there is no possibility to fully establish the facts on the essential issues and the real factual situation must be established in administrative proceedings. 
- If the court finds that the challenged administrative act has been issued by an incompetent body and then with a judgment it will declare the administrative act invalid.

- If the court annuls the challenged administrative act, in the judgment it will assign the respondent body to bring a new act within 15 days from the day the judgment becomes final. The respondent body is then connected with the legal opinion of the court in relation to the implementation of the material provision and the positions that belong to the procedure.

- If the respondent body does not act on the basis of the court's remarks then the court itself will decide the case with a judgment which in its entirety replaces the contested administrative act, while on the plaintiff's proposal the body which has not acted on the basis of the court will impose a fine of $20 \%$ of the monthly salary.

\section{Conclusion}

In order to ensure legality in the work (activity) of the administration, in addition to other forms of control, judicial control of the legality of the work of the administration should be exercised.

The indictment in the administrative procedure presents the last opportunity for the party to request judicial intervention in the administrative activity after the exhaustion of legal remedies. The indictment provides a guarantee for the party requesting judicial intervention to hope and believe that his lost or violated right by the administrative body can be gained or corrected again by the judiciary after ascertaining the illegality of the act and after a meritorious decision in full jurisdiction of the matter contested by the plaintiff.

The importance of the lawsuit in the administrative activity is clearly seen in the fact that the initiation of the lawsuit is an alarm to the judicial body to control the administrative activity, as the initiation of administrative dispute through the lawsuit does not mean that we have an administration that respects and implements legal provisions but we have a completely different situation, an administration that does not represent a guarantee for the party to exercise the rights based on the constitution and the law but an administration which is guided by different points of view either by not properly interpreting the law, or by affirming incomplete factual situation, causes non-fulfillment of obligations on the one hand and violation of the right of the party on the other.

From the research on the functioning of the work of the Administrative Court on the review of cases initiated by this court, including the period before the crisis of the Covid-19 pandemic, and the period of non-functioning of state institutions in general and judicial institutions in particular, we can find irresponsibility in the work done by this court as the number of cases initiated before this court in the normal period of operation constitutes a large number of unresolved cases which number from month to month is followed and increased and with this number the court is overwhelmed with unresolved cases that is not a consequence of a pandemic but a consequence of an irresponsibility of this court in its control over the activity of the administration.

From the reports published by this court, the year 2019 concludes with a total of 5036 unresolved cases, which reflects an irresponsibility on the part of this court in the work it does. Most lawsuits are initiated by Public Supplies, Denationalization, Customs Taxes and the Disability Health Pension Fund, which also reflect an inefficient administration severely violating the rights of citizens, as the large number of cases or lawsuits initiated results in an administrative activity which violates the rights of citizens based on law, while the large number of solved cases which are increasing from month to month shows a double violation of law and law.

Therefore, in conclusion, I would suggest that the number of court cases would be smaller if the administrative bodies that are competent for the cases in which we have more lawsuits are controlled by the devolutive bodies in terms of implementation and misuse of laws, and in case of ascertainment of responsibility against them to be 
sanctioned sanctions while the Administrative Court competent to decide on the basis of indictments, during the receipt and distribution of cases to specific judges, submitted cases to be evidenced and to control the process of processing the same and in case of negligence by the judges, it would be insufficient to sanction them themselves with a fine, but it would be more effective to suspend them and replace them with responsible young staff who respect the citizens and their rights in their state.

\section{Bibliography}

- Stavileci, Esat. Introduction to Administrative Sciences, Pristina, 1997.

- Stavileci, Esat. Notions and Principles of Public Administration, Pristina, 2007.

- Stavileci, Esat. Sokoli, Agur. Batalli, Mirlinda. Administrative Law, Administration, Control, Responsibility and Computerization, Prishtina, 2010.

- Stavileci, Esat. Batalli, Mirlinda. Sadushi, Sokol. Administrative Law, Organization and Administrative Activity, Prishtina, 2012.

- Dobjani, Ermir. Administrative Law, Tirana, 2003.

- Dobjani, Ermir. Puto, Erlir. Toska, Ela. Get away, Erajd. Control over Public Administration, Tirana, 2013.

- Pollozhani, Bajram. Salihu, Lazim. Administrative Procedure and Administrative Conflict, logos-A, 2004

- Sadushi, Sokol. Administrative Law 2, Third Revised Edition, Tirana, 2005.

- Sokoli, Agur. Control of Administrative Work and Its Political Responsibility, Pristina, 2009

- Sokoli, Agur. Administrative Procedural Law, Pristina, 2014.

- Ibraimi, Xhemazie. Compulsiveness of the Verdicts, International Magazine for Social Sciences "VIZIONE", ISSN, 1409-8962, Skopje, January, 2014.

- Ibraimi, Xhemazie, Administrative Dispute - Instrument of Legality Control of Administrative Acts and Protecting Rights and Freedoms of Citizens, International Magazine "JUSTICIA", ISSN 1827-8454 UDC: 34 Tetovo, March, 2014.

- Ibraimi, Xhemazie. Case of Administrative Dispute, ISSN 2410-3918 (Print), ISSN 2410-8693 (online), IMPACT FACTOR, November, 2015.

- Ibraimi Xhemazie, Reasons for Cancellation of Administrative Decision by Administrative Court, Academic Journal of Business, Administration, Low and Social Sciences, ISSN 2410-8693, ISSN 2410 3918, Korik, 2016.

- Ibraimi Xhemazie, Extraordinary Legal Remedies in the Administrative Conflict, IISTE, ISSN 22243240 (paper), ISSN 2224-3259 (online), August, 2019.

- Gelevski, Simeon. Grizo, Naum. Davitkovski, Borce. Administrative Law, Skopje, 1997. DanevaPavlovska Ana, Ombudsman, Skopje, 2000.

- Gelevski, Simeon. Administrative Process Law, Skopje, 2003.

- Grizo, Naum. Gelevski, Simeon. Davitkovski, Borce. Daneva-Pavlovska, Ana. Public Administration, Skopje, 2008.

- Gelevski, Simeon. Davitkovski, Borce. Grizo, Naum. Administrative Law, Skopje, 2011.

- Grizo, Naum. Gelevski, Simeon. Davitkovski, Borce. Daneva-Pavlovska, Ana. Administrative Law, Skopje, 2008.

- Borkovic, Ivo. Administrative Law, Zagreb, 1987.

- Popovi,, Slavoljub. Administrative Dispute in Theory and Practice, Belgrade, 1979.

- Stjepanovi,, Nikola. Administrative Law, Belgrade, 1991

- Law on Administrative Conflict of RM, Official Gazette of RM no.62 / 06.

- Law on Administrative Conflict Of RM Official Gazette of RM no. 150/2010

- Law on Administrative Conflict Of RM Official Gazette of RM no.08-1579 / 2

- Law on Administrative Disputes of the Republic of Kosovo, no. 03 / L

- Report of the work of the Administrative Court for 2019 and 2020, (website of Upraven Sud na RCM). 
Table No.1 presents: The work report of the Administrative Court for the period from July 2019 to December 2019, for the total number of cases received, reviewed, and unresolved cases which are in court process.

\begin{tabular}{|c|c|c|c|c|c|c|}
\hline \multicolumn{7}{|c|}{ Administrative Court - report for the period: 7.2019 - 12.2019} \\
\hline Area & \multicolumn{6}{|c|}{ Евиденции во судска управа } \\
\hline Type of the object & \multicolumn{6}{|c|}{ Евиденции во судска управа } \\
\hline Subtype of object & Unresolved & Newly received & incorrectly & Total at work & Resolved & Rest \\
\hline $\begin{array}{l}\text { Cases from the court } \\
\text { administration }\end{array}$ & 48 & 1002 & 0 & 1050 & 1037 & 13 \\
\hline $\begin{array}{l}\text { Confidential cases in court } \\
\text { administration }\end{array}$ & 0 & 5 & 0 & 5 & 5 & 0 \\
\hline Total - Type of the object & 48 & 1007 & 0 & 1055 & 1042 & 13 \\
\hline Total - Area & 48 & 1007 & 0 & 1055 & 1042 & 13 \\
\hline Area & \multicolumn{6}{|c|}{ Прекршоци во управни спорови } \\
\hline Type of the object & \multicolumn{6}{|c|}{ Прекршоци во управни спорови } \\
\hline Subtype of object & Unresolved & Newly received & $\begin{array}{l}\text { incorrectly } \\
\text { recorded }\end{array}$ & Total at work & Resolved & Rest \\
\hline Administrative offenses - & 226 & 246 & 1 & 471 & 260 & 211 \\
\hline Administrative offenses - & 44 & 43 & 0 & 87 & 42 & 45 \\
\hline $\begin{array}{l}\text { Administrative offenses - } \\
\text { taxes }\end{array}$ & 12 & 29 & 0 & 41 & 15 & 26 \\
\hline $\begin{array}{l}\text { Administrative offenses - } \\
\text { competition }\end{array}$ & 11 & 0 & 0 & 11 & 3 & 8 \\
\hline Total - Type of the object & 293 & 318 & 1 & 610 & 320 & 290 \\
\hline Total - Area & 293 & 318 & 1 & 610 & 320 & 290 \\
\hline Area & \multicolumn{6}{|c|}{ Преставки и поплаки } \\
\hline Type of the object & \multicolumn{6}{|c|}{ Преставки и поплаки } \\
\hline Subtype of object & Unresolved & Newly received & $\begin{array}{l}\text { incorrectly } \\
\text { recorded }\end{array}$ & Total at work & Resolved & Rest \\
\hline Free access to information & 15 & 37 & 0 & 52 & 32 & 20 \\
\hline $\begin{array}{l}\text { Records of complaints and } \\
\text { arievances }\end{array}$ & 56 & 359 & 0 & 415 & 414 & 1 \\
\hline Total - Type of the object & 71 & 396 & 0 & 467 & 446 & 21 \\
\hline Total - Area & 71 & 396 & 0 & 467 & 446 & 21 \\
\hline Area & \multicolumn{6}{|l|}{ Управна Area } \\
\hline Type of the object & \multicolumn{6}{|l|}{ Управна Area } \\
\hline Subtype of object & Unresolved & Newly received & $\begin{array}{l}\text { incorrectly } \\
\text { recorded }\end{array}$ & Total at work & Resolved & Rest \\
\hline Various administrative cases & 12 & 9 & 2 & 19 & 9 & 10 \\
\hline Administrative disputes & 0 & 0 & 0 & 0 & 0 & 0 \\
\hline $\begin{array}{l}\text { Request for execution of a } \\
\text { judament of the }\end{array}$ & 16 & 15 & 0 & 31 & 15 & 16 \\
\hline $\begin{array}{l}\text { Request for protection of } \\
\text { fundamental riahts and }\end{array}$ & 12 & 9 & 0 & 21 & 9 & 12 \\
\hline Total - Type of the object & 40 & 33 & 2 & 71 & 33 & 38 \\
\hline Total - Area & 40 & 33 & 2 & 71 & 33 & 38 \\
\hline Area & \multicolumn{6}{|l|}{ Управни спорови } \\
\hline Type of the object & \multicolumn{6}{|l|}{ Управни спорови } \\
\hline Subtype of object & Unresolved & Newly received & $\begin{array}{l}\text { incorrectly } \\
\text { recorded }\end{array}$ & Total at work & Resolved & Rest \\
\hline $\begin{array}{l}\text { Administrative disputes from } \\
\text { PDIE sZ . ZO riahts }\end{array}$ & 629 & 396 & 0 & 1025 & 506 & 519 \\
\hline $\begin{array}{l}\text { Administrative disputes from } \\
\text { urbanism and }\end{array}$ & 284 & 398 & 7 & 675 & 308 & 367 \\
\hline $\begin{array}{l}\text { Administrative disputes from } \\
\text { customs. fees. }\end{array}$ & 644 & 525 & 1 & 1168 & 577 & 591 \\
\hline $\begin{array}{l}\text { Administrative disputes from } \\
\text { denationalization. }\end{array}$ & 1203 & 426 & 1 & 1628 & 349 & 1279 \\
\hline $\begin{array}{l}\text { Administrative disputes from } \\
\text { oroperty law }\end{array}$ & 301 & 304 & 2 & 603 & 391 & 212 \\
\hline $\begin{array}{l}\text { Administrative disputes from } \\
\text { Dublic procurement rights }\end{array}$ & 1755 & 977 & 4 & 2728 & 1022 & 1706 \\
\hline Total - Type of the object & 4816 & 3026 & 15 & 7827 & 3153 & 4674 \\
\hline Total - Area & 4816 & 3026 & 15 & 7827 & 3153 & 4674 \\
\hline Total & 5268 & 4780 & 18 & 10030 & 4994 & 5036 \\
\hline
\end{tabular}


Table no. 2 presents: The work report of the Administrative Court for the month January-2020

\section{Administrative Court - report for the month $\mathbf{1 . 2 0 2 0}$}

\begin{tabular}{|c|c|c|c|c|c|c|}
\hline area & \multicolumn{6}{|c|}{ Records in the court administration } \\
\hline Object type & \multicolumn{6}{|c|}{ Records in the court administration } \\
\hline Subtype of object & Unresolved & Newly received & $\begin{array}{l}\text { Wrongly } \\
\text { misled }\end{array}$ & Total at work & Resolved & Rest \\
\hline $\begin{array}{l}\text { Cases from the court } \\
\text { administration }\end{array}$ & 13 & 161 & $\frac{0}{0}$ & 174 & 107 & 67 \\
\hline Total - type of item & 13 & 161 & 0 & 174 & 107 & 67 \\
\hline Total - area & 13 & 161 & 0 & 174 & 107 & 67 \\
\hline area & \multicolumn{6}{|c|}{ Violations in administrative disputes } \\
\hline Object type & \multicolumn{6}{|c|}{ Violations in administrative disputes } \\
\hline Subtype of object & Unresolved & Newly received & $\begin{array}{l}\text { Wrongly } \\
\text { misled }\end{array}$ & Total at work & Resolved & Rest \\
\hline Administrative offenses - & 211 & 53 & 1 & 263 & 48 & 215 \\
\hline $\begin{array}{l}\text { Administrative offenses - } \\
\text { customs }\end{array}$ & 45 & 7 & 0 & 52 & 11 & 41 \\
\hline $\begin{array}{l}\text { Administrative offenses - } \\
\text { taxes }\end{array}$ & 26 & 4 & 0 & 30 & 5 & 25 \\
\hline $\begin{array}{l}\text { Administrative offenses - } \\
\text { competition }\end{array}$ & 8 & 0 & 0 & 8 & 2 & 6 \\
\hline Total - type of item & 290 & 64 & 1 & 353 & 66 & 287 \\
\hline Total - area & 290 & 64 & 1 & 353 & 66 & 287 \\
\hline area & \multicolumn{6}{|c|}{ Преставки и поплаки } \\
\hline Object type & \multicolumn{6}{|c|}{ Преставки и поплаки } \\
\hline Subtype of object & Unresolved & Newly received & $\begin{array}{l}\text { Wrongly } \\
\text { misled }\end{array}$ & Total at work & Resolved & Rest \\
\hline Free access to information & 20 & 1 & $\frac{0}{0}$ & 21 & 19 & 2 \\
\hline $\begin{array}{l}\text { Records of complaints and } \\
\text { grievances }\end{array}$ & 1 & 54 & 0 & 55 & 40 & 15 \\
\hline Total - type of item & 21 & 55 & 0 & 76 & 59 & 17 \\
\hline Total - area & 21 & 55 & 0 & 76 & 59 & 17 \\
\hline area & \multicolumn{6}{|l|}{ Управна area } \\
\hline Object type & \multicolumn{6}{|l|}{ Управна area } \\
\hline Subtype of object & Unresolved & Newly received & $\begin{array}{l}\text { Wrongly } \\
\text { misled }\end{array}$ & Total at work & Resolved & Rest \\
\hline Various administrative cases & 10 & 1 & 0 & 11 & 2 & 9 \\
\hline Administrative disputes & 0 & 0 & 0 & 0 & 0 & 0 \\
\hline $\begin{array}{l}\text { Request for execution of a } \\
\text { iudament of the }\end{array}$ & 16 & 7 & 0 & 23 & 7 & 16 \\
\hline $\begin{array}{l}\text { Request for protection of } \\
\text { fundamental riahts and }\end{array}$ & 12 & 1 & 0 & 13 & 0 & 13 \\
\hline Total - type of item & 38 & 9 & 0 & 47 & 9 & 38 \\
\hline Total - area & 38 & 9 & 0 & 47 & 9 & 38 \\
\hline area & \multicolumn{6}{|l|}{ Управни спорови } \\
\hline Object type & \multicolumn{6}{|l|}{ Управни спорови } \\
\hline Subtype of object & Unresolved & Newly received & $\begin{array}{l}\text { Wrongly } \\
\text { misled }\end{array}$ & Total at work & Resolved & Rest \\
\hline $\begin{array}{l}\text { Administrative disputes from } \\
\text { PDIE. SZ ZO riahts }\end{array}$ & 519 & 56 & 1 & 574 & 81 & 493 \\
\hline $\begin{array}{l}\text { Administrative disputes from } \\
\text { urbanism and }\end{array}$ & 367 & 45 & 0 & 412 & 49 & 363 \\
\hline $\begin{array}{l}\text { Administrative disputes from } \\
\text { customs. fees. }\end{array}$ & 591 & 361 & 0 & 952 & 109 & 843 \\
\hline $\begin{array}{l}\text { Administrative disputes from } \\
\text { denationalization. }\end{array}$ & 1279 & 50 & 1 & 1328 & 74 & 1254 \\
\hline $\begin{array}{l}\text { Administrative disputes from } \\
\text { oronerty law }\end{array}$ & 212 & 50 & 3 & 259 & 54 & 205 \\
\hline $\begin{array}{l}\text { Administrative disputes from } \\
\text { public orocurement_riahts }\end{array}$ & 1706 & 242 & 2 & 1946 & 215 & 1731 \\
\hline Total - type of item & 4674 & 804 & 7 & 5471 & 582 & 4889 \\
\hline Total - area & 4674 & 804 & 7 & 5471 & 582 & 4889 \\
\hline Total & 5036 & 1093 & 8 & 6121 & 823 & 5298 \\
\hline
\end{tabular}


Tabela Nr. 3 paraqet: Raportin e punës e Gjykatës Administrative për muajin Shkur-2020

Administrative Court - report for the month 2.2020

\begin{tabular}{|c|c|c|c|c|c|c|}
\hline \multirow{3}{*}{\begin{tabular}{|c|} 
Area \\
Object type \\
Subtype of object
\end{tabular}} & \multicolumn{6}{|c|}{ Records in the court administration } \\
\hline & \multicolumn{6}{|c|}{ Records in the court administration } \\
\hline & Unresolved & Newly received & $\begin{array}{l}\text { Wrong } \\
\text { seduced }\end{array}$ & Total at work & Resolved & Rest \\
\hline Cases from court & 67 & 140 & 0 & 207 & 183 & 24 \\
\hline \multicolumn{7}{|l|}{ Confidential items in court } \\
\hline Total - type of item & 67 & 146 & 0 & 213 & 188 & 25 \\
\hline Total - area & 67 & 146 & 0 & 213 & 188 & 25 \\
\hline Area & \multicolumn{6}{|c|}{ Violations in administrative disputes } \\
\hline Object type & \multicolumn{6}{|c|}{ Violations in administrative disputes } \\
\hline Subtype of object & Unresolved & Newly received & $\begin{array}{l}\text { Wrong } \\
\text { seduced }\end{array}$ & Total at work & Resolved & Rest \\
\hline Administrative offenses - & 215 & 23 & 0 & 238 & 34 & 204 \\
\hline $\begin{array}{l}\text { Administrative offenses - } \\
\text { customs }\end{array}$ & 41 & 3 & 0 & 44 & 19 & 25 \\
\hline $\begin{array}{l}\text { Administrative offenses - } \\
\text { taxes }\end{array}$ & 25 & 4 & 0 & 29 & 2 & 27 \\
\hline \begin{tabular}{|l|}
$\begin{array}{l}\text { Administrative offenses - } \\
\text { competition }\end{array}$ \\
\end{tabular} & 6 & 1 & 0 & 7 & 0 & 7 \\
\hline \begin{tabular}{|c|} 
Total - type of item \\
\end{tabular} & 287 & 31 & 0 & 318 & 55 & 263 \\
\hline Total-area & 287 & 31 & 0 & 318 & 55 & 263 \\
\hline Area & \multicolumn{6}{|c|}{ Complaints and grievances } \\
\hline Type of Area & \multicolumn{6}{|c|}{ Complaints and grievances } \\
\hline Subtype of object & Unresolved & Newly received & $\begin{array}{l}\text { Wrong } \\
\text { seduced }\end{array}$ & Total at work & Resolved & Rest \\
\hline $\begin{array}{l}\text { Free access to } \\
\text { information }\end{array}$ & 2 & 7 & 0 & 9 & 4 & 5 \\
\hline $\begin{array}{l}\text { Records of complaints } \\
\text { and complaints }\end{array}$ & 15 & 65 & 0 & 80 & 47 & 33 \\
\hline \begin{tabular}{|c|} 
Total - type of item \\
\end{tabular} & 17 & 72 & 0 & 89 & 51 & 38 \\
\hline Total-area & 17 & 72 & 0 & 89 & 51 & 38 \\
\hline Area & \multicolumn{6}{|c|}{ Administrative area } \\
\hline Type of Area & \multicolumn{6}{|c|}{ Administrative area } \\
\hline Subtype of object & Unresolved & Newly received & $\begin{array}{l}\text { Wrong } \\
\text { seduced }\end{array}$ & Total at work & Resolved & Rest \\
\hline Various administrative cases & 9 & 3 & 1 & 11 & 10 & 1 \\
\hline Administrative disputes & 0 & 0 & 0 & 0 & 0 & 0 \\
\hline $\begin{array}{l}\text { at the judgment of the } \\
\text { Administrative }\end{array}$ & 16 & 4 & 0 & 20 & 6 & 14 \\
\hline $\begin{array}{l}\text { Request protection } \\
\text { fundamental rights and freedoms }\end{array}$ & 13 & 5 & 0 & 18 & 2 & 16 \\
\hline Total - type of item & 38 & 12 & 1 & 49 & 18 & 31 \\
\hline Total - area & 38 & 12 & 1 & 49 & 18 & 31 \\
\hline Area & \multicolumn{6}{|c|}{ Administrative disputes } \\
\hline Type of Area & \multicolumn{6}{|c|}{ Administrative disputes } \\
\hline Subtype of object & Unresolved & Newly received & $\begin{array}{l}\text { Wrong } \\
\text { seduced }\end{array}$ & Total at work & Resolved & Rest \\
\hline health-sanitary & 493 & 49 & 1 & 541 & 91 & 450 \\
\hline water economy, & 363 & 53 & 2 & 414 & 75 & 339 \\
\hline $\begin{array}{l}\text { questions, travel } \\
\text { documents, vehicles, weapons, }\end{array}$ & 843 & 443 & 0 & 1286 & 118 & 1168 \\
\hline expropriation, & 1254 & 62 & 0 & 1316 & 98 & 1218 \\
\hline $\begin{array}{l}\text { property law } \\
\text { area, cadastre and " }\end{array}$ & 205 & 56 & 1 & 260 & 79 & 181 \\
\hline duty, lawyers, & 1731 & 152 & 1 & 1882 & 256 & 1626 \\
\hline Total - area & 4889 & 815 & 5 & 5699 & 717 & 4982 \\
\hline Total - area & 4889 & 815 & 5 & 5699 & 717 & 4982 \\
\hline Total - & 5298 & 1076 & 6 & 6368 & 1029 & 5339 \\
\hline
\end{tabular}


Tabela Nr. 4 paraqet: Raportin e punës e Gjykatës Administrative për muajin Mars-2020 Administrative Court - report for the month $\mathbf{3 . 2 0 2 0}$

\begin{tabular}{|c|c|c|c|c|c|c|}
\hline Area & \multicolumn{6}{|c|}{ Records in the court administration } \\
\hline Object type & \multicolumn{6}{|c|}{ Records in the court administration } \\
\hline Subtype of object & Unresolved & Newly received & Wrongly misled & Total at work & Resolved & Rest \\
\hline $\begin{array}{l}\text { Cases from court } \\
\text { directs }\end{array}$ & 24 & 80 & 0 & 104 & 102 & 2 \\
\hline $\begin{array}{l}\text { Confidential items in } \\
\text { court administration }\end{array}$ & 1 & 1 & 0 & 2 & 2 & 0 \\
\hline Total - type of item & 25 & 81 & $\mathbf{0}$ & 106 & 104 & 2 \\
\hline Total - area & 25 & 81 & $\mathbf{0}$ & 106 & 104 & 2 \\
\hline Area & \multicolumn{6}{|c|}{ Violations in administrative disputes } \\
\hline Object type & \multicolumn{6}{|c|}{ Violations in administrative disputes } \\
\hline Subtype of object & Unresolved & Newly received & Wrongly misled & Total at work & Resolved & Rest \\
\hline Administrative offenses - & 204 & 52 & 2 & 254 & 37 & 217 \\
\hline $\begin{array}{l}\text { Administrative offenses - } \\
\text { customs }\end{array}$ & 25 & 8 & 0 & 33 & 0 & 33 \\
\hline $\begin{array}{l}\text { Administrative offenses - } \\
\text { taxes }\end{array}$ & 27 & 10 & 0 & 37 & 4 & 33 \\
\hline $\begin{array}{l}\text { Administrative offenses - } \\
\text { competition }\end{array}$ & 7 & 2 & 0 & 9 & 0 & 9 \\
\hline Total - type of item & 263 & 72 & 2 & 333 & 41 & 292 \\
\hline Total - area & 263 & 72 & 2 & 333 & 41 & 292 \\
\hline Area & \multicolumn{6}{|c|}{ Complaints and grievances } \\
\hline Object type & \multicolumn{6}{|c|}{ Complaints and grievances } \\
\hline Subtype of object & Unresolved & Newly received & Wrongly misled & Total at work & Resolved & Rest \\
\hline $\begin{array}{l}\text { Free access to } \\
\text { information }\end{array}$ & 5 & 4 & 0 & 9 & 8 & 1 \\
\hline $\begin{array}{l}\text { Records of complaints } \\
\text { and complaints }\end{array}$ & 33 & 38 & 0 & 71 & 67 & 4 \\
\hline Total - type of item & 38 & 42 & 0 & 80 & 75 & 5 \\
\hline Total - area & 38 & 42 & $\mathbf{0}$ & 80 & 75 & 5 \\
\hline Area & \multicolumn{6}{|c|}{ Administrative area } \\
\hline Object type & \multicolumn{6}{|c|}{ Administrative area } \\
\hline Subtype of object & Unresolved & Newly received & Wrongly misled & Total at work & Resolved & Rest \\
\hline Various administrative cases & 1 & 17 & 0 & 18 & 12 & 6 \\
\hline Administrative disputes & 0 & 0 & 0 & 0 & 0 & 0 \\
\hline $\begin{array}{l}\text { at the judgment of the } \\
\text { Administrative }\end{array}$ & 14 & 2 & 0 & 16 & 3 & 13 \\
\hline $\begin{array}{l}\text { Request protection } \\
\text { fundamental rights and freedoms }\end{array}$ & 16 & 7 & 0 & 23 & 1 & 22 \\
\hline Total - type of item & 31 & 26 & $\mathbf{0}$ & 57 & 16 & 41 \\
\hline Total - area & 31 & 26 & $\mathbf{0}$ & 57 & 16 & 41 \\
\hline Area & \multicolumn{6}{|c|}{ Administrative disputes } \\
\hline Object type & \multicolumn{6}{|c|}{ Administrative disputes } \\
\hline Subtype of object & Unresolved & Newly received & Wrongly misled & Total at work & Resolved & Rest \\
\hline health-sanitary & 450 & 56 & 0 & 506 & 70 & 436 \\
\hline water economy, & 339 & 52 & 2 & 389 & 59 & 330 \\
\hline $\begin{array}{l}\text { questions, travel } \\
\text { documents, vehicles, weapons, }\end{array}$ & 1168 & 95 & 1 & 1262 & 211 & 1051 \\
\hline expropriation, & 1218 & 75 & 0 & 1293 & 92 & 1201 \\
\hline property law & 181 & 85 & 1 & 265 & 72 & 193 \\
\hline area, cadastre and " & 1626 & 142 & 1 & 1767 & 198 & 1569 \\
\hline duty, lawyers, & 4982 & 505 & 5 & 5482 & 702 & 4780 \\
\hline Total - type of item & 4982 & 505 & 5 & 5482 & 702 & 4780 \\
\hline Total - area & 5339 & 726 & 7 & 6058 & 938 & 5120 \\
\hline
\end{tabular}


Tabela Nr. 5 paraqet: Raportin e punës e Gjykatës Administrative për muajin Prill-2020

\section{Administrative Court - report for the month $\mathbf{4 . 2 0 2 0}$}

\begin{tabular}{|c|c|c|c|c|c|c|}
\hline Area & \multicolumn{6}{|c|}{ Records in the court administration } \\
\hline Object type & \multicolumn{6}{|c|}{ Records in the court administration } \\
\hline Subtype of object & Unresolved & Newly received & $\begin{array}{l}\text { incorrectly } \\
\text { recorded }\end{array}$ & Total at work & Resolved & Rest \\
\hline $\begin{array}{l}\text { Cases from the court } \\
\text { administration }\end{array}$ & 2 & 35 & 0 & 37 & 34 & 3 \\
\hline Total - type of item & 2 & 35 & $\begin{array}{ll}0 & \\
0\end{array}$ & 37 & 34 & 3 \\
\hline Total - area & 2 & 35 & 0 & 37 & 34 & 3 \\
\hline Area & \multicolumn{6}{|c|}{ Violations in administrative disputes } \\
\hline Object type & \multicolumn{6}{|c|}{ Violations in administrative disputes } \\
\hline Subtype of object & Unresolved & Newly received & $\begin{array}{l}\text { incorrectly } \\
\text { recorded }\end{array}$ & Total at work & Resolved & Rest \\
\hline Administrative offenses - & 217 & 19 & 0 & 236 & 14 & 222 \\
\hline $\begin{array}{l}\text { Administrative offenses - } \\
\text { customs }\end{array}$ & 33 & 2 & 0 & 35 & 3 & 32 \\
\hline $\begin{array}{l}\text { Administrative offenses - } \\
\text { taxes }\end{array}$ & 33 & 0 & 0 & 33 & 2 & 31 \\
\hline $\begin{array}{l}\text { Administrative offenses - } \\
\text { comnetition }\end{array}$ & 9 & 0 & 0 & 9 & 0 & 9 \\
\hline Total - type of item & 292 & 21 & 0 & 313 & 19 & 294 \\
\hline Total - area & 292 & 21 & 0 & 313 & 19 & 294 \\
\hline Area & \multicolumn{6}{|c|}{ Complaints and grievances } \\
\hline Object type & \multicolumn{6}{|c|}{ Complaints and grievances } \\
\hline Subtype of object & Unresolved & Newly received & $\begin{array}{l}\text { incorrectly } \\
\text { recorded }\end{array}$ & Total at work & Resolved & Rest \\
\hline Free access to information & 1 & 6 & 0 & 7 & 3 & 4 \\
\hline $\begin{array}{l}\text { Records of complaints and } \\
\text { grievances }\end{array}$ & 4 & 12 & 0 & 16 & 15 & 1 \\
\hline Total - type of item & 5 & 18 & 0 & 23 & 18 & 5 \\
\hline Total - area & 5 & 18 & 0 & 23 & 18 & 5 \\
\hline Area & \multicolumn{6}{|c|}{ Administrative area } \\
\hline Object type & \multicolumn{6}{|c|}{ Administrative area } \\
\hline Subtype of object & Unresolved & Newly received & $\begin{array}{l}\text { incorrectly } \\
\text { recorded }\end{array}$ & Total at work & Resolved & Rest \\
\hline Various administrative cases & 6 & 1 & 0 & 7 & 0 & 7 \\
\hline $\begin{array}{l}\text { Request for protection of } \\
\text { fundamental riahts and }\end{array}$ & 22 & 0 & 0 & 22 & 1 & 21 \\
\hline $\begin{array}{l}\text { Request for execution of a } \\
\text { iudament of the }\end{array}$ & 13 & 2 & 0 & 15 & 2 & 13 \\
\hline Total - type of item & 41 & 3 & 0 & 44 & 3 & 41 \\
\hline Total - area & 41 & 3 & 0 & 44 & 3 & 41 \\
\hline Area & \multicolumn{6}{|c|}{ Administrative disputes } \\
\hline Object type & \multicolumn{6}{|c|}{ Administrative disputes } \\
\hline Subtype of object & Unresolved & Newly received & $\begin{array}{l}\text { incorrectly } \\
\text { recorded }\end{array}$ & Total at work & Resolved & Rest \\
\hline $\begin{array}{l}\text { Administrative disputes from } \\
\text { PDIE. SZ ZO riahts }\end{array}$ & 436 & 37 & 0 & 473 & 73 & 400 \\
\hline $\begin{array}{l}\text { Administrative disputes from } \\
\text { urbanism and }\end{array}$ & 330 & 23 & 0 & 353 & 23 & 330 \\
\hline $\begin{array}{l}\text { Administrative disputes from } \\
\text { customs fees }\end{array}$ & 1051 & 73 & 0 & 1124 & 74 & 1050 \\
\hline $\begin{array}{l}\text { Administrative disputes from } \\
\text { denationalization. }\end{array}$ & 1201 & 6 & 0 & 1207 & 67 & 1140 \\
\hline $\begin{array}{l}\text { Administrative disputes from } \\
\text { bronertv law }\end{array}$ & 193 & 70 & 1 & 262 & 30 & 232 \\
\hline $\begin{array}{l}\text { Administrative disputes from } \\
\text { public procurement, riahts }\end{array}$ & 1569 & 94 & 0 & 1663 & 117 & 1546 \\
\hline Total - type of item & 4780 & 303 & 1 & 5082 & 384 & 4698 \\
\hline Total - area & 4780 & 303 & 1 & 5082 & 384 & 4698 \\
\hline Total & 5120 & 380 & 1 & 5499 & 458 & 5041 \\
\hline
\end{tabular}




\begin{tabular}{|l|c|c|c|c|c|}
\hline \multicolumn{1}{|c|}{ Lëndë } & $\begin{array}{c}\text { Lëndë të } \\
\text { mëhershme }\end{array}$ & Të pranuara & $\begin{array}{c}\text { Gjithsej në } \\
\text { shqyrtim }\end{array}$ & $\begin{array}{c}\text { Të } \\
\text { zgjidhura }\end{array}$ & Në proces \\
\hline $\begin{array}{l}\text { Korik-dhjetor } \\
2019\end{array}$ & 5268 & 4762 & 1003 & 4994 & 5036 \\
\hline Janar / 2020 & 5036 & 1084 & 6121 & 823 & 5298 \\
\hline Shkurt/2020 & 5298 & 1070 & 6368 & 1029 & 5339 \\
\hline Mars/2020 & 5339 & 719 & 6058 & 938 & 5120 \\
\hline Prill/2020 & 5120 & 379 & 5499 & 458 & 5041 \\
\hline
\end{tabular}

The data in the table are processed based on the data obtained from the monthly, quarterly, semi-quarterly work reports of the Administrative Court of the RMV, from July 2019 to December 2019, as well as the month: January, February, March, April-2020. 